JAMP: Jurnal Adminitrasi dan Manajemen Pendidikan

Volume 4 Nomor 4 Desember 2021, Hal : 350 - 357

Tersedia Online di http://journal2.um.ac.id/index.php/jamp/

ISSN 2615-8574 (online)

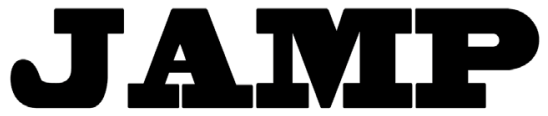

JURNAL ADMINISTRASI DAN MANAJEMEN PENDIDIKAN

\title{
CORRELATION BETWEEN ORGANIZATIONAL CULTURE AND WORKING CLIMATE
}

\author{
Akram \\ Institut Agama Islam Negeri Bone - Jalan Hos Cokroaminoto, Regency of Bone, South Sulawesi \\ E-mail: akrambone19@gmail.com No. Hp: 082393183037
}

\begin{abstract}
This study aims to: 1)describe the reality of organizational culture; 2)describe the reality of the work climate, and 3)examine the correlation between organizational culture and work climate at Madrasah Tsanawiyah(Islamic Middle School) 1 Bone South Sulawesi. This research uses a quantitative methodology with a correlational design to explain the research questions. The instrument used to measure the variables of this study was a questionnaire then analyzed with descriptive statistics and inferential statistics use analysis of the productmoment with SPSS version 25 software. The result of the study show in descriptive of organizational culture is in the very conducive category of $86,38 \%$ and work climate is in the conducive category of $81,09 \%$. In addition, the analysis of inferential with correlation product moment analysis suggests that there is a positive and significant correlation between organizational culture and work climate, signified by a correlation coefficient of $51,4 \%$, which is a mid-level of correlation. With the organizational culture at MTSN 1 Bone in the form of values and norms that have a positive impact on the creation of a conducive work climate.
\end{abstract}

Keywords: The Organization; Organizational Culture; Work Climate

organizational culture plays an important role in the creation of a conducive work climate. This is in line with Wirawan's opinion (2008) which says that organizational culture is rooted in organizational values, norms, beliefs, and assumptions, while the working climate in the organization represents the internal environment of the organization and is rooted in the organizational culture. It is clear that the creation of a working climate in the organization is inseparable from the culture contained in an organization. Culture and work climate can not be separated because a good culture will create a conducive work climate that ultimately forms the behavior of individuals who are in an organization. The working climate in the organization is rooted in culture because in general, the climate is temporary or can change while the culture is eternal. That is why the working climate in an organization relies heavily on the culture that develops in a particular organization. Organizational culture is important in creating a conducive working climate. The prevailing habits in MTsN 1 Bone that reflect the culture of the organization can be said to be positive habits such as routinely carrying out dhuha prayer activities before carrying out learning and many other positive habits. Similarly, the rules are so strict that they are made using the system of sanctioning points or credit points violations of students, although there are still some students who still violate some existing rules. The habits and rules that apply in a madrasah, organized to form the character of students or form student disciplinary behavior that reflects the culture of the organization so as to create a conducive working.

Research conducted by Nandang Najmulmunir, et. al. (2009) on the relationship of organizational culture and organizational communication with teacher performance in educational journals. Zainuddin (2017) in his research on the influence of the principal's leadership behavior and organizational culture on the performance of Islamic religious education teachers in elementary, junior high, high school, and vocational schools in Fakfak District. Dedeh Sofia Hasanah (2010) in her research on the influence of training education (training) teacher leadership and work climate on the performance of elementary 
school teachers in Babakancikao Subdistrict Purwakarta. Research conducted by Anak Agung Nyoman Darma (2009) on the contribution of principal leadership, organizational culture, and school work climate to the professional quality of teachers at SMA Negeri 1 Sukawati.

Previous studies have shed light that this scientific article is new, as it is more concerned with the organization's cultural correlation with the working climate. It is clear that the novelty of this article is not in doubt because previous studies are very different from these studies or articles.

The research problem or hypothesis in this study is an associative hypothesis that asks the relationship between two or more variables, namely whether there is a correlation between the organizational culture and the working climate in MTsN 1 Bone.

Organizational culture is important in creating a conducive work climate. The habits that apply at MTsN 1 Bone that reflect the organizational culture can be said to be positive habits such as routinely carrying out dhuha prayers before carrying out learning and many other positive habits. Likewise, the applicable rules are made using a system of sanctions points or student credit violations, although there are still some students who violate some of the existing rules. The customary rules that apply in madrasas are held to shape students' character and shape student behavior that reflects the organizational culture so as to create a conducive work climate.

\section{METHOD}

This research was conducted in Jalan Letjen. Soekawati Bone Regency, South Sulawesi Province. This type of research is a quantitative research that is correlational. Correlational research is research conducted to test the relationship between two or more variables and to test how large the level of relationship between two or more variables (Sukardi, 2013: 166). The population of this study is all teachers in MTsN 1 Bone as many as 120 teachers. The research sample of 55 teachers using sample determination based on the Slovin formula (Riduwan, 2012: 65). The data collection techniques used in this study are questionnaires. The questionnaire was compiled based on indicators from each dimension of this study variable then circulated to 55 teachers in MTsN 1 Bone. Data collection techniques using questionnaires compiled based on indicators from each dimension of this research variable were then circulated to 55 teachers at MTsN 1 Bone South Sulawesi. The questionnaire is a key instrument in collecting data in the field related to organizational culture and working climate in MTsN 1 Bone. Questionnaires are organized based on the following instrument grids.

Tabel 1. instrument Grid

\begin{tabular}{lll}
\hline No. & \multicolumn{1}{c}{ Variable } & \multicolumn{1}{c}{ Indicator } \\
\hline 1 & Organizational Culture & 1. Value \\
& & 2. Norm \\
2 & Work Climate & 1. Physical Climate \\
& & 2. Social Climate \\
\hline
\end{tabular}

After obtaining the data or responses of respondents to the questionnaire, it is then analyzed with descriptive statistics and inferential statistics using product-moment correlation analysis with the help of SPSS software version 25.

\section{RESULTS}

\section{Organizational Culture}

The results of the research obtained in the field related to organizational cultural variables in MTsN 1 Bone through a research questionnaire with a total of 55 respondents, can be analyzed descriptively using SPSS version 25 software with the following outputs: 
Table 2. Descriptive Statistics of Organizational Culture

\begin{tabular}{llllllll}
\hline & N & Range & Minimum & Maximum & Sum & Mean & Std. Deviation \\
\hline Organizational Culture & 55 & 17 & 78 & 95 & 4751 & 86,38 & 3,832 \\
Valid N (listwise) & 55 & & & & & & \\
\hline
\end{tabular}

Based on the table, it can be known that 55 teachers in MTsN 1 Bone who were respondents to the study obtained a minimum score of 78 and a maximum value of 95 . The overall answer from the respondents was obtained by 4,751 with an average response of 86.38 respondents and a standard deviation of 3,832 .

The average respondent's response is based on the data obtained, further interpreted in the interpretation guidelines based on the following categories.

Table 3. Interpretation of Organizational Culture Categories

\begin{tabular}{llll}
\hline Interval & \multicolumn{1}{c}{ Categories } & Frequency & Percentage \\
\hline $20-36$ & Very Unconducive & 0 & $0 \%$ \\
$37-52$ & Not Conducive & 0 & $0 \%$ \\
$53-68$ & Quite Conducive & 0 & $0 \%$ \\
$69-84$ & Conducive & 13 & $23,63 \%$ \\
$85-100$ & Very Conducive & 42 & $76,36 \%$ \\
Total & & 55 & $100 \%$ \\
\hline
\end{tabular}

Based on the table, it can be known that the average response from 55 respondents is 86.38 at intervals of $85-100$ with a frequency of 42 people and a percentage of $76.36 \%$ who understand that the culture of the organization in MTsN 1 Bone Bone District is in the category is very conducive.

\section{Working Climate}

The results of the research obtained in the field related to working climate variables in MTsN 1 Bone through a research questionnaire with a total of 55 respondents, can be analyzed descriptively using SPSS version 25 software with the following outputs:

Table 4. Descriptive Statistics of The Working Climate

\begin{tabular}{llllllll}
\hline & N & Range & Minimum & Maximum & Sum & Mean & Std. Deviation \\
\hline Working Climate & 55 & 17 & 75 & 92 & 4460 & 81,09 & 3,792 \\
Valid N (listwise) & 55 & & & & & & \\
\hline
\end{tabular}

Based on the SPSS output table, it can be known that 55 teachers in MTsN 1 Bone South Sulawesi who were respondents to the study obtained a minimum score of 75 and a maximum value of 92 . The overall answer from the respondents was obtained by 4,460 with an average response of 81.09 respondents and a standard deviation of 3,792.

The average respondent's response is based on the data obtained, further interpreted in the interpretation guidelines as follows:

Table 5. Interpretation of Working Climate Categories

\begin{tabular}{llll}
\hline Interval & \multicolumn{1}{c}{ Categories } & Frequency & Percentage \\
\hline $20-36$ & Very Unconducive & 0 & $0 \%$ \\
$37-52$ & Not Conducive & 0 & $0 \%$ \\
$53-68$ & Quite Conducive & 0 & $0 \%$ \\
$69-84$ & Conducive & 44 & $80 \%$ \\
$85-100$ & Very Conducive & 11 & $20 \%$ \\
Total & & 55 & $100 \%$ \\
\hline
\end{tabular}

Based on the table can be known that the average response of 55 respondents, namely 81.09 is at intervals of 69-84 with a frequency of 44 people and a percentage of $80 \%$ who give understanding that the working climate in MTsN 1 Bone Bone district is in the conducive category. 


\section{Inferential Analysis}

\section{Data Normality Test}

The normality test is one of the prerequisite tests that aims to find out whether the data obtained is normal or not. This is a prerequisite that must be met for the next inferential analysis.

Testing normality on organizational culture data and working climate in MTsN 1 Bone using onesample Kolmogrov-Smirnov test analysis with the help of SPSS version 25 software. The basis of decision making in normality test with one-sample Kolmogrov-Smirnov analysis is as follows: If the value of significance (Sig.) $>0.05$, then it can be said that the data in the study is normally distributed. If the significance value (Sig.) $<0.05$, then it can be said that the data in the study are not normally distributed.

The following will be presented output table spss version 25 test of normality data of organizational culture and working climate in MTsN 1 Bone South Sulawesi.

Table 6. Data Normality Test

\begin{tabular}{lll}
\hline & & Unstandardized Residual \\
\hline $\mathrm{N}$ & Mean & 55 \\
Normal Parameters &, 0000000 \\
Most Extreme Differences & Std. Deviation & 3,25361642 \\
& Absolute &, 079 \\
& Positive &, 079 \\
& Negative &,- 069 \\
Kolmogorov-Smirnov Z & &, 587 \\
Asymp. Sig. (2-tailed) & &, 881 \\
\hline
\end{tabular}

a. Test distribution is Normal.

b. Calculated from data.

Based on the SPSS output table, it is understood that the significance of Asymp. Sig. (2-tailed) has a value of 0.881 which indicates greater than 0.05 further assuming that the data is normally distributed because it is in accordance with the basis of decision-making in the kolmogorov-smirnov $\mathrm{Z}$ normality test which states that if the value of significance (Sig.) is greater than 0.05 then the research data is normally distributed. Thus, data obtained from the response of respondents in MTsN 1 Bone South Sulawesi can be declared normal distribution.

\section{Data Linearity Test}

The data linearity test is intended to determine whether two variables have a significant linear relationship or vice versa. The technique used in testing data linearity is to use test for linearity with the help of SPSS software version 25. The basis of decision making whether there is a linear relationship in the data obtained in the field or not is to refer to the comparison of the value of significance (Sig.) with 0.05 . More details may refer to the following statement: If the deviation from linearity significance value is greater than 0.05 then there is a significantly linear relationship between variables. If the deviation from linearity significance value is less than 0.05 then there is no significant linear relationship between variables.

Next will be presented the results of testing linearity data between the culture of the organization and the working climate can be seen in the following table. 
Table 7. Data Linearity Test

\begin{tabular}{clllllll}
\hline & & & $\begin{array}{c}\text { Sum of } \\
\text { Squares }\end{array}$ & df & $\begin{array}{c}\text { Mean } \\
\text { Square }\end{array}$ & F & Sig. \\
\hline & Between Groups & (Combined) & 316,654 & 14 & 22,618 & 1,967 &, 048 \\
& & Linearity & 204,900 & 1 & 204,900 & 17,822 &, 000 \\
Working & & Deviation from & 111,754 & 13 & 8,596 &, 748 &, 707 \\
$\begin{array}{c}\text { Climate } \\
\text { Organizational } \\
\text { Culture }\end{array}$ & & Linearity & & & & & \\
& Within Groups & & 459,891 & 40 & 11,497 & & \\
\hline
\end{tabular}

Based on the SPSS output table, it can be seen that the significance value (Sig.) obtained from deviation from linearity is 0.707 which indicates greater than 0.05 further assuming that the data has a significant linear relationship because it corresponds to the basis of decision making in linearity tests stating that if the significance value (Sig.) deviation from linearity is greater than 0.05 then there is a significant linear relationship between variables. Thus, data related to the relationship between organizational cultural variables and working climate variables in MTsN 1 Bone South Sulawesi can be said to have a linear relationship of significance.

\section{Hypothesis Test}

The hypothesis tested aims to determine whether there is a correlation or there is no correlation between the culture of the organization and the working climate. Inferential statistical analysis used is correlation product-moment through the help of SPSS version 25 software application. The results of the hypothesis test can be seen in the following output table:

Table 8. Correlation between Organizational Culture and Work Climate

\begin{tabular}{|llll}
\hline & & Organizational Culture & Work Climate \\
\hline Organizational Culture & Pearson Correlation & 1 &, $514^{* *}$ \\
& Sig. (2-tailed) & &, 000 \\
& $\mathrm{~N}$ & 55 & 55 \\
& Pearson Correlation &, $514^{* *}$ & 1 \\
Work Climate & Sig. (2-tailed) &, 000 & \\
& $\mathrm{~N}$ & 55 & 55 \\
\hline
\end{tabular}

**. Correlation is significant at the 0.01 level (2-tailed).

Based on the output table spss version 25 it can be known that the magnitude of the correlation between organizational cultural variables and working climate variables in MTsN 1 Bone South Sulawesi can be seen in sig. (2-tailed) obtained a value of 0.000 indicating that the value is less than 0.01 (with a significance of $1 \%$ ) which means that the correlation of the two variables is significant at a confidence figure of $99 \%$ so it can be said that the correlation between organizational culture and the working climate applies to the entire population. Then at pearson correlation is 0.514 .0 .514 is at an interval of 0.40-0.599 indicating a strong relationship level as listed in the following table:

Table 9. Interpretation of Coefficient of Organizational Cultural Correlation with Work Climate

\begin{tabular}{lll}
\hline Correlation Value & Coefficient Interval & Correlation Rate \\
\hline $0,00-0,199$ & Very Low \\
& $0,20-0,399$ & Low \\
0,514 & $0,40-0,599$ & Medium \\
& $0,60-0,799$ & Strong \\
& $0,80-1,000$ & Very Strong \\
\hline
\end{tabular}

Based on the table, it can be understood that the correlation between organizational culture and work climate has a moderate level of correlation, so it can be decided that the hypothesis is accepted because there is a positive and significant correlation between the organizational culture and the working climate in MTsN 1 Bone South Sulawesi. 


\section{DISCUSSION}

Analysis of research data on organizational cultural variables in MTsN 1 Bone is very conducive because it is characterized by the application of values and norms that are fairly very effective. Researchers are not surprised by these results, because researchers really feel the culture embedded in the study site such as attitudes, mutual respect, and other positive behaviors. This is in accordance with the view of Buhler (2007: 291) which states that culture is seen as a code of conduct of members of the organization because culture can glue and maintain the organization through a system of trust and shared values. It is clear that culture is a guideline in organizing according to the opinion of Maartje Paais \&Jozef R. Pattiruhu (2020) that Culture is the essence of what is essential in organizations. The activities of member commands and prohibitions describe something that is done and not done that regulates the behavior of members. So, culture contains what may or may not be done so that it can be stated as a guideline used to carry out organizational activities. Positive behavior skewed by members of the organization is a manifestation of the culture that exists in the organization. This indicates that culture can be measured by paying attention to how behavior is skewed by members of the organization. According to Triwahyuni, L., (2014) organizational culture with the application of school values and norms, can have a positive effect on the success of schools, one of which is improving teacher performance. The application of values and norms is integral in producing positive behaviors. The positive behavior practiced in MTsN 1 Bone gives the view that there has been a conducive organizational culture in the madrasah. A conducive culture is characterized by standards attached to the person that influence moral considerations, response to others, and commitment to personal and organizational goals (M. Taufiq, 2017: 192). This is in line with Weerasinghe's opinion (2017) which states that the organizational culture will empower teamwork and increase the spirit of work in their workplace, to achieve good performance results. Good morals, manners and mutual respect, and commitment to common goals skewed by members of the organization are the hallmarks of an organizational culture conducive to a madrasah. It is clear that a conducive organizational culture is characterized by the behavior that members of the organization are in.

The reality of the working climate in MTsN 1 Bone South Sulawesi is in a conducive category characterized by the creation of a feeling of comfort, safety, and fun in carrying out duties and responsibilities as a member of the organization. Supardi (2016: 121) revealed that the working climate in madrasah is a comfortable situation and atmosphere around madrasah so as to improve academic achievement. Convenience is an important aspect that can have a positive effect in improving work performance by members of the organization. The spirited attitude that is skewed by members of the organization, in this case, is the citizens of MTsN 1 Bone signaling that the working climate is created conducive. This is in accordance with the opinion of Kompri (2017: 178) which states that a conducive working climate is needed for teachers to foster encouragement in teachers to work more vigorously. The feeling of safety and comfort gives teachers a distinct impetus to carry out high-spirited work that is characteristic of a conducive working climate. The working climate indicates that there is a physical and social climate so that madrasah personnel feels safer and comfortable in carrying out their duties and responsibilities which will ultimately have a positive effect on the development of institutions, one of which is effective and efficient learning. This is in line with the opinion of Ideswal, et al. (2020) A conducive school climate both physical and non-physical is the basis for the implementation of effective and productive learning.

Organizational culture plays an important role in the creation of a conducive work climate. It is expressed by Wirawan (2008) that the organizational culture is rooted in the values, norms, beliefs, and assumptions of the organization, while the working climate in the organization represents the internal environment of the organization and is rooted in the organizational culture. The creation of a working climate in the organization is inseparable from the culture contained in an organization. Culture and work climate can not be separated from each other because a conducive culture will create a conducive work climate that ultimately forms the behavior of individuals who are in an organization. The working climate in the organization is rooted in culture because in general, the climate is temporary or can change while the culture is eternal. That is why the working climate in an organization relies heavily on the culture that develops in a particular organization. Therefore, the culture and climate of educational 
organizations, especially schools, are a fair part of having an influence on the goals of educational achievement. (Haromain, 2019). In addition, Paschal \&Nizam (2016) revealed that the culture of the organization will affect the performance of employees. This is in line with gupta's opinion, et al. (2012) that organizational culture is able to improve employee productivity and organizational performance. The strong organizational culture of an organization will help improve performance levels (Awadh \&Alyahya, 2018). The more culturally conducive to an organization, the more conducive the climate or work atmosphere will be so that the resulting impact is determined by how the culture of the organization in an institution. A conducive school climate and culture encourages every school citizen to act and do what is best that leads to high student achievement. (Laelatu Zahro, 2020). It is justified by Rian Nurizka and Abdul Rahim (2020) the process of character-building students in education is inseparable from the efforts of the school to create a school climate that teaches the characters of students. The school climate can be realized from school culture which is a priority in shaping the character of students. Cultural or climate organization is one of the opportunities to develop human resources through aspects of changing attitudes and behaviors, which are expected to be able to adjust to current and future challenges. (Agus Purwanto, et. al., 2020). In other words, culture is one of the determinants or factors that determine whether or not the working climate is conducive to an institution or organization.

\section{CONCLUSIONS AND SUGGESTIONS}

\section{Conclusions}

This study can be concluded that there is a positive and significant correlation between the organizational culture and the working climate in MTsN 1 Bone with a medium level of relationship with a correlation coefficient value of 0.694 . The analysis of the study means that a conducive organizational culture will create a conducive working climate as well.

Thus, the madrasah, both the head of the madrasah, teachers and students should continue to strive to create a conducive organizational culture through the application of values and norms that underlie positive behavior so that members of the organization can carry out their duties and responsibilities with a pleasant atmosphere that ultimately gives a positive effect to the madrasah, not least the success of the madrasah. Terkusus for teachers should be able to create a conducive working climate in order to carry out fun learning so that students can feel happy and more motivated to carry out learning.

\section{Suggestions}

It is recommended to further researchers study more in-depth science, especially the culture and climate of the organization so that further research can complement the results that are not yet present in the findings of this study.

\section{REFERENCES}

Awadh, A. M., \& Alyahya, M. S., 2018. Impact of organizational culture on employee performance. Indian Journal of Management, (Online), Vol. 11, No. 6, (https://doi.org/10.17010/pijom/2018/v11i6/128442, diakses 4 Maret 2021)

Buhler, Patricia. Tanpa Tahun. Alpha Teach Yourself: Management Skills in 24 Hours. Terjemahan oleh Sugeng Haryanto dkk. 2007. Jakarta: Prenada Media Group.

Chuabey, D. S., et al., 2012. Impact of Organization culture on employee motivation and job performance. International Journal of Research in Commerce and Management, (Online), Vol. 3, No. 5, (https://www. researchgate.net/publication/280529193_Impact_Of__Organization_Culture_On_Employee_Motivation_ And_Job_Performance, diakses 4 Maret 2021).

Darma, Anak Agung Nyoman. Kontribusi Kepemimpinan Kepala Sekolah, Budaya Organisasi, dan Iklim Kerja Sekolah Terhadap Kualitas Profesional Guru di SMA Negeri 1 Sukawati, Jurnal Administrasi Pendidikan, (Online), Vol. 3 No. 2. (http:// http://119.252.161.254/e-journal/index.php/jurnal_ap/article/view/389, diakses 26 Februari 2021). 
Haromain, 2019. Kajian Budaya dan Iklim dalam Organisasi Pendidikan. Jurnal Visionary, (Online), Vol. 4, No. 2 , (https://ojs.ikipmataram.ac.id/index.php/visionary/article/view/3003/ 2044, diakses 9 Maret 2021)

Hasanah, Dedeh Sofia. Pengaruh Pendidikan Latihan (diklat) Kepemimpinan Guru dan Iklim Kerja terhadap Kinerja Guru Sekolah Dasar se-Kecamatan Babakancikao Kabupaten Purwakarta. Jurnal Penelitian Pendidikan, (Online), Vol. 11 No. 2. (http://jurnal.upi.edu/file/8-dedeh_sofia_hasanah.pdf, diakses 27 Februari 2021).

Kompri. (2017). Standardisasi Kompetensi Kepala Sekolah: Pedekatan Teori untuk Praktek Profesional. Jakarta: Kencana.

Najmulmunir, Nandang, et. al. 2009. Hubungan Budaya Organisasi dan komunikasi organisasi dengan kinerja guru. Jurnal Edukasi, (Online), Vol. 1 No. 2 (http://jurnal.unismabekasi.ac.id/index.php/edukasi/article/ view/693/579, Diakses 17 September 2018).

Nurizka, Rian dan Abdul Rahim. 2020. INTERNALISASI NILAI-NILAI PANCASILA DALAM MEMBENTUK KARAKTER SISWA MELALUI BUDAYA SEKOLAH. Jurnal Pendidikan dan Pembelajaran ke-SD-an, (Online), Vol. 7, No. 1, (https://journal.upy.ac.id/index.php/es/article/view/478, diakses 9 Maret 2021).

Paais, Maartje \& Jozef R. Pattiruhu. 2020. Effect of Motivation, Leadership, and Organizational Culture on Satisfaction and Employee Performance. Journal of Asian Finance, Economics and Business, (Online), Vol. 7, No. 8, (https://www.koreascience.or. kr/article/JAKO202026061031735.page, diakses 4 Maret 2021).

Paschal, A. O., \& Nizam, D. I. 2016. Effects of Organisational Culture on Employees Performance. International Journal of Accounting and Business Management, (Online), Vol. 4, No. 1, (https://doi.org/10.24924/ ijabm/2016.04/v4.iss1/19.26, diakses 4 Maret 2021)

Purwanto, Agus, et. al.. 2020. Dampak Kepemimpinan, Budaya Organisasi dan Perilaku Kerja Inovatif Terhadap Kinerja Pegawai Puskesmas. Jurnal Ilmu Kesehatan masyarakat, (Online), Vol. 9, No. 1, (http://journals. stikim.ac.id/index.php/jikm/article/download/473/349, diakses 9 Maret 2021)

Riduwan.( 2012). Dasar-Dasar Statistika. Bandung: Alfabeta.

Sukardi. (2013). Metode Penelitian Pendidikan. Jakarta: Bumi Aksara.

Supardi. (2016). Kinerja Guru. Cet. III; Jakarta: Rajawali Pers, 2016.

Triwahyuni, L., et al. 2014. The Effect of Organizational Culture, Transformational Leadership and Self-Confidence to Teachers' Performance. International Journal of Managerial Studies and Research, (Online), Vol. 2, No. 10, (https://lppm.unpak.ac.id/Intl_journal_ unpak/2014\%20Lulus $\% 20$ Triwahyuni\%20\&\%20Thamrin $\% 20$ Abdullah\%20\&\%20Widodo\%20Sunaryo.pdf, diakses 4 Maret 2021).

Weerasinghe, G.. 2017. Organization culture impacts on employee motivation: A case study on an apparel company in Sri Lanka. International Journal of Multidisciplinary Research and Development, (Online), Vol. 4, No. 4, (https://www.semanticscholar.org/paper/Organization-culture-impacts-on-employee-A-case-on-Weerasingh e/74d54363f5f112ade669e48b5928dbb0 a92997d4. diakses 4 Maret 2021).

Wirawan. Budaya dan Iklim Organisasi: Teori Aplikasi dan Penelitian. Cet. II; Jakarta: Salemba Empat, 2008.

Zahro, Laelatu. 2020. Strategi Kepala Sekolah dalam Pembinaan Iklim dan Budaya Sekolah di SDI Taruna Surabaya. Jurnal Keislaman, (Online), Vol. 3, No. 1, (http://ejournal.kopertais4.or.id/susi/index.php/JK/ article/view/3118, diakses 9 Maret 2021).

Zainuddin, 2017. Pengaruh Perilaku Kepemimpinan Kepala Sekolah dan Budaya Organisasi terhadap kinerja guru pendidikan agama Islam di SD, SMP, SMA,dan SMK se kabupaten Fakfak. Jurnal Lisan Al-Hal, (Online), Vol. 9 No. 2 (http://ejournal.kopertais4.or.id/tapalkuda/index.php/lisan /article/view/3054/2257, diakses 27 Agustus 2018). 